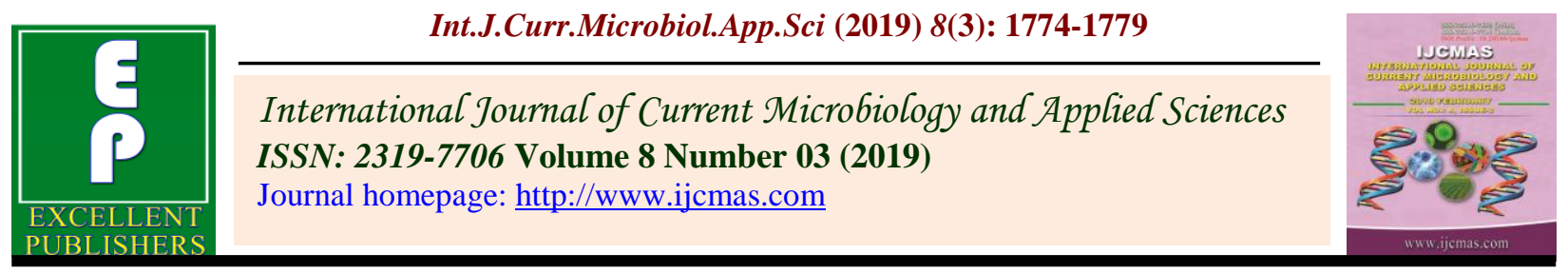

Original Research Article

https://doi.org/10.20546/ijcmas.2019.803.207

\title{
Preferential Characteristics of JG-11 Bengal Gram Variety as Experienced by Farmers of Yadgir District, Karnataka, India
}

\author{
Moulasab $^{1 *}$, D.M. Chandargi ${ }^{2}$ and D.G. Satihal ${ }^{3}$
}

\author{
${ }^{1}$ Agricultural Extension Education, ${ }^{2}$ College of Agriculture, ${ }^{3}$ Agricultural Research Station, \\ Bheemarayanagudi, University of Agricultural Sciences, \\ Raichur-584 104, Karnataka, India \\ *Corresponding author
}

\section{A B S T R A C T}

\begin{tabular}{|l|}
\hline K e y w o r d s \\
JG-11 Bengal \\
Gram, Preferential \\
Characteristics and \\
Variety \\
\hline Article Info \\
\hline $\begin{array}{l}\text { Accepted: } \\
\text { 15 February } 2019 \\
\text { Available Online: } \\
\text { 10 March } 2019\end{array}$ \\
\hline
\end{tabular}

The study was conducted in Shorapur and Yadagir taluks of Yadagir district on impact of JG-11 bengal gram on farmers revealed that majority of the JG-11 growers expressed that the characteristics namely; bold grains, higher flowering and seed setting, resistance to wilt, comes up well in dry land and high yielding capacity as positive ones. The major negative characters of JG-11 were single seed pod and shrivelled pods. The practices namely foliar application of urea, use of growth promoter after 35 days (NAA) was followed by only $15.00 \%$ of farmers. Very few farmers followed fertilizer application as recommended. Higher average yield was obtained by farmers in Shorapur taluk with 10.50 $\mathrm{q} /$ ha followed by Yadgir farmers with $10.00 \mathrm{q} / \mathrm{ha}$. In case of Annigeri-1 variety average yield of $8.00 \mathrm{q} /$ ha was obtained by Yadgir farmers followed by $7.50 \mathrm{q} / \mathrm{ha}$ by Shorapur farmers. Very few farmers were growing desi varieties with average yield of $4.25 \mathrm{q} / \mathrm{ha}$. In case of JG 11 the C:B ratio was 1:2.3 and it was 1:1.86 in Annigeri-1. Majority expressed continued adoption of JG-11 (60.00\%) and even expand the area under JG-11 provided they are assured of price of at least Rs. $4000=00$ per qtl.

\section{Introduction}

The Hyderabad Karnataka region of Karnataka state has six districts, among these Yadgir district comprising of three taluks namely; Shahpur, Shorapur and Yadagir is the most background district. The district receives annual rainfall of $819.38 \mathrm{~mm}$ which is erratic and unevenly distributed, affecting the crops cultivated. Droughts are frequent in the district occurring every 3-4 years. Terrain has natural slope leading to soil and nutrient loss.
The major crops grown include Tur, Ground nut, Cotton, Green gram in Kharif and Bengal gram and jowar in rabi. There is high incidence of migration-both distress and undistress, $60 \%$ of the population between the age group of 15-45 years migrate to Mumbai, Mangalore and Bangalore in search of employment. Thus migration has been an accepted phenomenon among the members of the community. Though agriculture being the main source of livelihood, higher dependence on rains and following unplanned cropping 
pattern under small holdings (1.71 ha. Average land holding) has made the conditions of farmers pathetic. Based on the preliminary discussion with farmers through FGDs it was found that farmers grow Bengal gram during rabi and they were growing varieties namely A-1 and other local varieties. The average yield of these varieties were very low 4-5 qt1/ha in case of A-1.

Bengal gram (Cicer arietinum) is the most important grain legume in the country covering 9.51 million ha and accounting to 68 per cent of the total global area of 13.20 million ha. and second most important legume after dry beans at the global level. Bengal gram cultivation in India The total production of Bengal gram in India stands at 8.88 million tons which is about 70 per cent of the total world production of 11.62 million tons. India, as the largest consumer and largest importer, is a major player in the global market for Bengal gram. It contributes to 40 per cent of total national pulse area under cultivation and 48 per cent of total national pulse production (Singh, 2013). Total area and production of Bengal gram is continuously rising in Karnataka indicating a strong and growing popularity for Bengal gram cultivation. The cultivation of Bengal gram in the country witnessed a marginal decline during the 1970's and 1980's but recovered to reach 95.1 lakh ha during decadal year 2010

JG-11 a drought tolerant Bengal gram variety was introduced in Karnataka during Rabi 2005-06. It had shown 14 percent increase in yield over the local Annigeri variety as per the information from officer of Joint Director of Agriculture, Yadgir. Farmers received fair price by cultivating JG-11 variety because of bold size. Even in drought condition the performance of JG-11 was good as expressed by the farmers compared to Annigeri variety. JG-11 had given yield of 15-20 q/ha this has very much attracted other farmers also and under irrigation just by two irrigations the yield can be increased upto $25 \%$. Also, JG-11 is tolerant to wilt and drought. It comes to maturity one week earlier than Annigeri. Department of Agriculture has distributed JG11 seeds to around 200 farmers of in Yadgir district the reaction of these farmers could be analysed with respect to performance.Hence the present study is carried out with the following specific objectives:

To analyse the characteristics (both positive and negative) of JG-11 as perceived by farmers and practices followed in cultivation.

To study the practices followed and constraints faced by farmers with respect to JG-11 Bengal gram variety.

\section{Materials and Methods}

The study was conducted during 2013 in Shorapur and Yadgir taluks of Yadgir district. Post fact research design was used. The list of farmers who were given the JG-11 seeds by KSDA was prepared from the RSKs in all the three taluks in the district and the RSKs where higher quantity of seeds distributed and more number of farmers covered were selected. From the list of farmers in the selected RSKs 33 farmers from Yadgir and 70 farmers from Shorapur were selected by following proportionate random sampling procedure. Thus, 103 farmers formed the sample size for the study and another $25 \mathrm{JG}$ 11 growers were considered for FGD in one village. Based on the objectives of the study an interview schedule was prepared to collect information from farmers. Personal interview method was followed and data were collected during February-march, 2013. FGD was carried out involving 25 farmers in Tangadgi village who had grown JG-11. Simple statistical tools like simple averages, ratios, percentages, mean and Standard deviation and others were employed to analyze the data to draw meaningful inferences. 


\section{Results and Discussion}

Characteristics of JG-11 as perceived by farmers

A perusal of data in the Table 1 revealed that Majority $(51.45 \%)$ of the farmers perceived that "yield is more" followed by a considerably higher parentage of farmers i.e. 29.12 and $20.38 \%$ who perceived that JG-11 has high flowering and seed setting quality and possess bold grains, respectively.

With respect to negative characteristics a considerable percentage of farmers (32.03) perceived that JG-11 has single seed and shrivelled pods. Followed by 27.18 percent who perceived that pest infestation is high (Table 2a).
Practices followed by farmers in JG-11 cultivation

The results presented in Table 2 reveals that Majority of the farmers followed the practices as recommended in case of date of sowing (51.51\% in Yadgir Taluk and 72.85 in Shorapur), Seed rate $(90.90 \%$ in Yadgir Taluk \& $77.14 \%$ in Shorapur).

Fertilizer (63.63\% in Yadgir Taluk and 72.85 in Shorapur), Method of harvesting manually (93.93\% in Yadgir Taluk and $98.57 \%$ ) in Shorapur), Spacing $30 * 10 \mathrm{~cm}(57.57 \%$ in Yadgir Taluk and $68.57 \%$ in Shorapur). Only few farmers followed the practices namely foliar application of urea, use of growth promoter after 35 days (NAA)

Table.1 Characteristics of JG-11 as perceived by farmers $n=103$

\begin{tabular}{|c|c|c|c|c|c|c|c|}
\hline $\begin{array}{l}\text { Sl. } \\
\text { no }\end{array}$ & Characteristics of JG-11 & \multicolumn{2}{|c|}{$\begin{array}{l}\text { Yadagir } \\
\mathrm{n} 1=33\end{array}$} & \multicolumn{2}{|c|}{$\begin{array}{c}\text { Shorapur } \\
\text { n2 }=70\end{array}$} & \multicolumn{2}{|c|}{ Total } \\
\hline & Positive & No & $\%$ & No & $\%$ & No & $\%$ \\
\hline 1 & $\begin{array}{l}\text { Grows well even in low winter } \\
\text { temperature }\end{array}$ & 3 & 9.09 & 3 & 4.28 & 6 & 5.66 \\
\hline 2 & Bold pods /grains & 10 & 30.30 & 11 & 15.71 & 21 & 20.38 \\
\hline 3 & $\begin{array}{l}\text { Resistant to powdery mildew and } \\
\text { wilt }\end{array}$ & 7 & 21.21 & 9 & 12.85 & 16 & 15.53 \\
\hline 4 & Yield is more & 13 & 39.39 & 40 & 57.14 & 53 & 51.45 \\
\hline 5 & Comes up even in dry farming also & 0 & 0.00 & 7 & 9.99 & 7 & 6.79 \\
\hline 6 & High flowering and seed setting & 15 & 45.45 & 15 & 21.42 & 30 & 29.12 \\
\hline \multicolumn{8}{|c|}{ Negative } \\
\hline 1 & Pest infection is high & 10 & 30.30 & 18 & 25.71 & 28 & 27.18 \\
\hline 2 & Single seed and shrivelled pod & 8 & 24.24 & 25 & 35.71 & 33 & 32.03 \\
\hline 3 & Suitable for only irrigation condition & 0 & 0.00 & 12 & 17.14 & 12 & 17.14 \\
\hline
\end{tabular}


Table.2 Influencing characteristics for adoption of JG-11 n=103

\begin{tabular}{|c|l|c|c|c|c|c|c|}
\hline \multirow{2}{*}{$\begin{array}{l}\text { S. } \\
\text { no }\end{array}$} & \multicolumn{1}{|c|}{ Characteristics } & \multicolumn{2}{|c|}{$\begin{array}{c}\text { Yadagir } \\
\text { n1 =33 }\end{array}$} & \multicolumn{2}{c|}{$\begin{array}{c}\text { Shorapur } \\
\text { n2 =70 }\end{array}$} & \multicolumn{2}{c|}{ Total } \\
\cline { 3 - 8 } & & No & No & $\%$ & No & $\%$ \\
\hline $\mathbf{1}$ & $\begin{array}{l}\text { Grows well even in low winter } \\
\text { temperature }\end{array}$ & 5 & 15.15 & 6 & 8.57 & 11 & 10.67 \\
\hline $\mathbf{2}$ & Comes up in dry farming also & 8 & 24.24 & 8 & 11.42 & 16 & 15.53 \\
\hline $\mathbf{3}$ & $\begin{array}{l}\text { Tasty Grains and suitable for sweets } \\
\text { making }\end{array}$ & 4 & 12.12 & 5 & 7.14 & 9 & 8.73 \\
\hline $\mathbf{4}$ & With stands cloudy climate & 6 & 18.18 & 9 & 12.85 & 15 & 14.56 \\
\hline $\mathbf{5}$ & High yield & 17 & 51.51 & 45 & 64.28 & 62 & 60.19 \\
\hline $\mathbf{6}$ & $\begin{array}{l}\text { Tolerance to powdery mildew and } \\
\text { wilt }\end{array}$ & 8 & 24.24 & 0 & 0.00 & 8 & 7.76 \\
\hline $\mathbf{7}$ & Marketing( more rate) & 19 & 57.57 & 35 & 49.99 & 54 & 52.42 \\
\hline $\mathbf{8}$ & $\quad$ Suitable for putani making & 17 & 51.51 & 15 & 21.42 & 32 & 31.06 \\
\hline
\end{tabular}

Table.2a Practices followed by farmers in Yadagi $n=33$

\begin{tabular}{|c|c|c|c|c|c|}
\hline \multirow{2}{*}{$\begin{array}{l}\text { SI. } \\
\text { no }\end{array}$} & \multirow[t]{2}{*}{ Practices } & \multicolumn{2}{|c|}{ JG.11variety } & \multicolumn{2}{|c|}{ Other Varieties } \\
\hline & & No & $\%$ & No & $\%$ \\
\hline 1 & Date of sowing (oct-15) & 17 & 51.51 & 20 & 60.60 \\
\hline 2 & Seed rate( $25 \mathrm{~kg} / \mathrm{acre})$ & 30 & 90.90 & 24 & 72.72 \\
\hline $\mathbf{3}$ & Seed treatment(trichoderma) & 19 & 57.57 & 18 & 54.54 \\
\hline 4 & Fertilizer (only DAP-2bags /acre) & 21 & 63.63 & 16 & 48.48 \\
\hline 5 & Spacing $30 * 10 \mathrm{~cm}$ & 19 & 57.57 & 11 & 33.33 \\
\hline 6 & Weedicide (Pendimethalin) & 5 & 15.15 & 3 & 9.09 \\
\hline 7 & Nipping & 21 & 63.63 & 10 & 30.30 \\
\hline 8 & Growth promoter after 35 days. NAA Foliar & 5 & 15.15 & 2 & 6.06 \\
\hline 9 & Foliar application of urea and calcium Nitrate & 5 & 15.15 & 5 & 15.15 \\
\hline 10 & Method of harvesting manually & 31 & 93.93 & 22 & 66.66 \\
\hline
\end{tabular}

Table.2b Practices followed by farmers in Yadagir $n=70$

\begin{tabular}{|c|l|c|c|c|c|}
\hline \multirow{2}{*}{$\begin{array}{c}\text { Sl. } \\
\text { no }\end{array}$} & \multicolumn{1}{|c|}{ Practices } & \multicolumn{2}{c|}{ JG.11 variety } & \multicolumn{2}{c|}{ Other Varieties } \\
\cline { 2 - 6 } & & No & $\%$ & No & $\%$ \\
\hline $\mathbf{1}$ & Date of sowing (Oct-15) & 51 & 72.85 & 19 & 27.14 \\
\hline $\mathbf{2}$ & Seed rate(25kg/acre) & 54 & 77.14 & 15 & 21.42 \\
\hline $\mathbf{3}$ & Seed treatment(trichoderma) & 29 & 41.42 & 39 & 55.71 \\
\hline $\mathbf{4}$ & Fertilizer (only DAP-2bags /acre) & 51 & 72.85 & 18 & 25.71 \\
\hline $\mathbf{5}$ & Spacing 30*10 cm & 48 & 68.57 & 21 & 29.99 \\
\hline $\mathbf{6}$ & Weedcide (Pendi methilien) & 18 & $25 . .71$ & 52 & 74.28 \\
\hline $\mathbf{7}$ & Nipping & 43 & 61.42 & 26 & 37.14 \\
\hline $\mathbf{8}$ & Growth promoter after 35days NAA Foliar & 19 & 27.14 & 50 & 71.42 \\
\hline $\mathbf{9}$ & Foliar application of urea and calcium Nitrate & 11 & 15.71 & 59 & 84.28 \\
\hline $\mathbf{1 0}$ & Method of harvesting manually & 69 & 98.57 & 1 & 1.42 \\
\hline
\end{tabular}


Table.3 Bengal gram varieties grown and their yield levels and B:C ratio $n=103$

\begin{tabular}{|c|c|c|c|c|c|c|c|c|c|c|}
\hline \multirow[t]{2}{*}{$\begin{array}{l}\text { Varietie } \\
\mathbf{s}\end{array}$} & \multicolumn{2}{|c|}{$\begin{array}{l}\text { Yadagir } \\
\text { n1 =33 }\end{array}$} & \multicolumn{3}{|c|}{ Average Yield /ha. } & \multicolumn{2}{|c|}{$\begin{array}{l}\text { Shorapur } \\
\mathrm{n} 2=70\end{array}$} & \multicolumn{3}{|c|}{ Average Yield / ha. } \\
\hline & No & $\%$ & Yield & $\begin{array}{c}\text { Cost of } \\
\text { prod }\end{array}$ & $\begin{array}{l}\text { B.C } \\
\text { ratio }\end{array}$ & No & $\%$ & Yield & $\begin{array}{c}\text { Cost of } \\
\text { prod }\end{array}$ & $\begin{array}{l}\text { B.C } \\
\text { ratio }\end{array}$ \\
\hline A-1 & 31 & 93.93 & 8.00 & 11500 & $1: 1.86$ & 47 & 1.89 & 7.50 & 11000 & $1: 1.90$ \\
\hline Local & 5 & 15.15 & 4.25 & 9500 & $1: 1.40$ & 5 & 1.51 & 5.00 & 9700 & $1: 1.45$ \\
\hline JG-11 & 33 & 99.99 & 10.00 & 11000 & $1: 2.3$ & 66 & 2.91 & 10.50 & 12000 & $1: 2.50$ \\
\hline
\end{tabular}

In case of Annegiri-1 and others varieties the practices followed by farmers were not as per recommendation by majority (Table $2 \mathrm{a} \& 2 \mathrm{~b}$ ).

Economics of JG-11 as compared to Anniger-1 from the experiences of farmers

The results presented in Table 3 reveals that The B:C Ratio was higher in JG-11 (1:2.5) compared to A-1 variety which was 1:1.90 In case of other local varieties grown in the study area the $\mathrm{B}: \mathrm{C}$ ratio was 1:0.45.

The average yield levels of JG-11 ranged from 10-10.5 q/ha compared to 7.5-8.0 q/ha in A-1 and 4.25 to $5.00 \mathrm{q} / \mathrm{ha}$ in other local varieties grown by farmers. The cost of production ranged from Rs.11,000-Rs.12,000 in JG-11 where as in case of A-1 it was Rs.11,000-Rs.11,500 and it was Rs.9500Rs.9700 in local varieties.

Practical constraints and suggestions as perceived by farmers

Market price was the major constraint faced by farmers. All the farmers opined that if remunerative prices are given to Bengal gram they would continue to adopt JG-11 as they are happy with the yield and bold grains of JG-11. They suggested that Govt. announce the MSP in advance of growing JG-11, otherwise there are no major problems with respect to JG-11 cultivation. This was revealed by farmers during FGD at Tangadgi village.

\section{Major recommendations/ Policy Implications}

The pulse breeder has to stress on the negative characters of JG-11 especially, single seed pod and shrivelled pods in their crop improvement programme

There is need to undertake extension activities by RSK and AEEC, Yadagir in organizing demonstrations to show the worth of practices namely foliar application of urea, use of growth promoter after 35 days (NAA) as these were followed by only $15.00 \%$ of farmers.

The farmers need to be educated regarding the importance of applying fertilizers as recommended.

The diffusion process is initiated by KSDA through seed distribution programme as most of the farmers came to know about the variety within last one year $(70.00 \%)$ and two years (23\%) and got the information through Dept. of Agriculture (90.00 \%) under the programme of seed distribution on subsidy. It has to become a demand driven initiative and in this direction the recent technologies are to be disseminated through mass media. University KVK and AEEC can take up 
extension activities to provide information through literature such as leaflets and folders

Market price is the major driving force for continued adoption of JG-11 (60.00\%) and even expansion of the area under JG-11 the government may be persuaded to announce the support price in advance.

In conclusion, the results revealed that majority of the JG-11 growers expressed that the characteristics namely; bold grains, higher flowering and seed setting, resistance to wilt, comes up well in dry land and high yielding capacity as positive ones. Farmers received fair price by cultivating JG-11 variety because of bold size. Even in drought condition the performance of JG-11 was good as expressed by the farmers compared to Annigeri variety. JG-11 had given yield of 15-20 q/ha this has very much attracted other farmers also and under irrigation just by two irrigations the yield can be increased upto $25 \%$. Also, JG-11 is tolerant to wilt and drought.

\section{References}

Anonymous, 2013a, Agriculture output. Econ. Intel. Service, 8(2): 64-78.

Anonymous, 2013-14, Economics Survey 2013-14, GOI, Ministry of Finance, Dept. of Economic Affairs.

Anonymous., 2013, International Encyclopedia of the social sciences, Crowell Collier and Mhillan inc.US.

Bandgar, S. G., Kude, N. R., and Bhople, R. S., 2004, Adoption of University recommended Cotton technologies and the constraints faced by the farmers. PKV. Res. J. 28(1): 91-95.

Sidram, 2008, Analysis of organic farming practices in Pigeonpea in Gulbarga district of Karnataka state. M. Sc. (Agri.) Thesis (Unpub.), Univ. Agric. Sci., Dharwad (India).

Tawde, N. D., 1994, Utilization pattern of agricultural technology in tribal social system. Maharashtra J. Ext. Edu., 13: 241-244.

\section{How to cite this article:}

Moulasab, D.M. Chandargi and Satihal, D.G. 2019. Preferential Characteristics of JG-11 Bengal Gram Variety as Experienced By Farmers of Yadgir District, Karnataka, India. Int.J.Curr.Microbiol.App.Sci. 8(03): 1774-1779. doi: https://doi.org/10.20546/ijcmas.2019.803.207 